\title{
Restrictive measures - sanctions compliance, implementation and judicial review challenges in the common foreign and security policy of the European Union
}

\author{
Nadia Zelyova ${ }^{1}$ \\ Accepted: 9 March 2021 / Published online: 31 March 2021 \\ (C) The Author(s) 2021
}

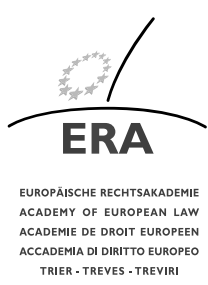

Abstract This article provides a comprehensive overview of EU restrictive measures applicable within the EU, the competences and legal evolution which lead to the implementation of Common Foreign and Security Policy restrictive measures (CFSP sanctions), and considers procedural issues, developments in the latest case law, and the challenges of securing compliance with EU sanctions, which reach beyond the territory of the EU.

Keywords UNSC - EU CFSP sanctions · Judicial review · Restrictive measures · UNSC sanctions · Freezing of funds · Third country standing · Compliance - Right to an effective judicial procedure

\section{Introduction}

While European foreign ministers approved the new European Global Human rights restrictive measures (sanctions) regime in early December 2020, targeting perpetrators of human rights violations, regardless of location and nationality as part of the European common foreign and security policy (CFSP), it is important to discuss the challenges posed by the contemporary restrictive measures regimes for those who have to comply with them, especially where respect for human rights within the procedural realities of the CFSP is at stake. ${ }^{1}$ At present, different states or international organisations issue sometimes conflicting or parallel restrictive measures, covering

\footnotetext{
${ }^{1}$ Council Decision (CFSP) 2020/1999 of 7.12.2020, Council Regulation (EU) 2020/1998 of 7.12.2020 concerning restrictive measures against serious human rights violations and abuses.
}

\footnotetext{
$\triangle$ N. Zelyova

n.j.zelyova@umail.leidenuniv.nl

1 LL.M. Candidate at the University of Leiden, Leiden, The Netherlands
} 
the same parties. Conflicting sanctions lead to litigation and to large expenses for entities, which have to seek judicial remedies for breach of obligations. Even if the sanctions are inapplicable, such breaches of obligations can cause negative consequences both financial and reputational De Burca [26] for the parties involved, whereas noncompliance can lead both to criminal and to civil sanctions for companies, management and everyone else involved. ${ }^{2}$ The purpose of this article which is based on the ERA seminar on External Relations Sanctions in December 2020, is thus to outline the EU restrictive measures framework, the hurdles regarding the implementation of, application of and compliance with such measures, and the challenges faced when contesting sanctions in the European courts.

Part II outlines restrictive measures as instruments adopted under the EU CFSP which can be directed both at states and at natural or legal persons [15]. The EU's Common Foreign and Security Policy (CFSP) reflects a focus on coherent external relations [40], an aim which the Council should be aware of when adopting CFSP decisions as it has a key role in shaping the CFSP policy. ${ }^{3}$ The CFSP is subject to the EU law principles enshrined in the Treaties and the Council, chaired by the High Representative, should be aware of other policies when acting in relation to CFSP measures, since it has decision-making functions in framing the CFSP policy. ${ }^{4}$ The formal procedural rules for effecting the CFSP policy through voting, also approved by the Council can differ, requiring unanimity or qualified majority voting on a preliminary consulted and agreed proposals, prepared by COREPER and the Political and Security Committee. ${ }^{5}$

The European Court of Justice, in assessing the predominant purpose or component of Council decisions, clarifies aspects of the CFSP which intertwine with other policy areas, adjudicating on the correct legal bases in which the Council decisions should be grounded. ${ }^{6}$ The role of the Council in shaping CFSP policy and decisions is almost independent from the Commission and the Parliament, except for a consultation requirement with the European Parliament, since the decisions the Council adopts, are not legislative acts. ${ }^{7}$ The exclusion of a legislative procedure results in a perceived limited role of the Court of Justice of the European Union (CJEU) in unison with the Member States 'desire to shield their foreign policy from "judicial activism" [40]. ${ }^{8}$

However the CFSP is related to the other areas of external action and since the EU is founded on the principle of the rule of law, its institutions have to respect

\footnotetext{
${ }^{2}$ Member States such as Netherlands impose criminal penalties for violations of restrictive measures. Other Member States impose civil/administrative penalties. See also Lester [33].

${ }^{3}$ R.A. Wessel, Larik, L. (Eds.) EU External Affairs Law, Text, Cases and Material (2 ${ }^{\text {nd }}$ Edition), Oxford: Hart Publishing, 2020, Chapter 9 [40].

${ }^{4}$ Art. 17(4), (5), Art. 18(3), Art. 23(1), Art. 27, Art. 30(1), 40 TEU.

${ }^{5}$ Art. 22(1) TEU, Art. 24(1) TEU, Art. 31(2) TEU, Art. 33 TEU, Art. 33(2) TEU, Art. 38(1) TEU, Art. 240 TFEU.

${ }^{6}$ Case C-244/17, European Commission v Council of the European Union, ECLI:EU:C:2018:662.

${ }^{7}$ See Art. 24 TEU, Art. 25 TEU, Art. 29 TEU, Art. 36 TEU, Art. 218(10) TFEU, Art. 275 TFEU, Art. 288 TFEU. However, Article 352 TFEU presumes the usage of a legislative procedure.

${ }^{8}$ R.A. Wessel, J. Larik (Eds.) EU External Affairs Law, Text, Cases and Material (2 ${ }^{\text {nd }}$ Edition), Oxford: Hart Publishing, 2020, Chapter 9 [40].
} 
fundamental rights, resulting in the Court's review of CFSP regulations legality, in line with effective judicial protection, in compliance with the Charter of Fundamental Rights. ${ }^{9}$ According to the case law of the European Court of Justice, the Court can give preliminary rulings on the validity of CFSP regulations, because the limitations on the Court's jurisdiction to review CFSP matters should be given a 'narrow interpretation'. 10

Regardless of the 'narrow interpretation' of limitations on judicial review of the CFSP (both as regards fundamental rights compliance and the procedural aspects of the CFSP acts) it is challenging to subject CFSP acts to judicial review by the European Court of Justice as is discussed in Parts II and III below where it is seen that the procedural manner in which decisions are taken on certain matters can influence the outcome of those decisions and produce varying effects for those targeted by them, while remaining protected from effective judicial review.

The main part of this article is Part II, which outlines the different restrictive measures and their hierarchy within the EU system. Following this, Part II introduces the challenges that measures cause to those concerned by them. It also introduces the EU Treaties' bases for the adoption of restrictive measures under the CFSP and illustrates the challenges to sanctions compliance and the implementation of conflicting and parallel sanctions through examples from EU and Member States' case law. Part III illustrates judicial review issues related to EU, US and UNSC restrictive measures as seen in recent case law. Part IV of this article concludes with a summary of the main findings.

\section{Overview of restrictive measures (sanctions) which are applicable within the EU}

There are three major restrictive measures regimes which EU Member States need to consider. The regime derived from the United Nations Security Council (UNSC), and implemented by the EU, the autonomous EU sanctions regime, which is independent from the UNSC regime, and third countries' sanctions with extra-territorial application like the US or other countries' sanctions. Restrictive measures can target non-EU countries because of polices. They can target entities, groups or organisations or individuals involved in terrorist activities or supporting targeted policies. ${ }^{11}$ Sanctions can be trade and restrictive measures, which are usually referred to as 'sanctions' although they are not punitive in nature [27]. They can be adopted by countries or international organisations through laws and regulations in pursuit of foreign policy and security objectives, including the fight against terrorism and nuclear proliferation.

\footnotetext{
${ }^{9}$ See Art. 47 Charter of Fundamental Rights, Art. 6, Art. 24(1), Art. 40, Art. 275(2) TEU, and Case C355/04 P Segi and Others v Council [2007], EC:C:2007:116, para. 51. See Wessel [40], Gutman [29], Vatsov [39], Kokott [31].

${ }^{10}$ Kadi and Al Barakaat International Foundation v Council and Commission (Joined Cases C-402/05 P and C-415/05 P Kadi and Al Barakaat v. Council and Commission [2008] ECR I-6351 (ECJ, 3 September 2008). Kadi v Commission and Council (Case T-85/09) [2010] ECLI:EU:T:2010:418 (GCEU, 30.9.2010). Case C-658/11 EP v Council (Mauritius), EU:C2014:2025, para 70, Case C-72/15 Rosneft, EU:C:2017:236. See Kanetake [19], See Weesel and Ecke [22].

${ }^{11}$ Ibid., supra 2 .
} 
Sanctions can be diverse in that their purpose can be to promote peace and security, or they may aim at preventing conflicts, supporting democracy, and defending the principles of international law [18, 27, 30]. At the same time their purpose can be preventative in the sense of preventing threats to national security, foreign policy, and the economy. Generally, sanctions aim at bringing about change in the policy or the conduct of those whom they are addressed to, in order to promote the objectives of the CFSP.

Sanctions lists which are adopted are published by the national competent authorities, specifying the sanctioned persons and the countries that are subject to the economic, trade and financial measures. Sanctioned persons are those against whom specific sanctions are issued. The sanctions prohibit conducting business with these persons and may include asset freezes and other economic measures. ${ }^{12}$ Restrictions can be applicable in various jurisdictions, prohibiting the conduct of business in certain geographical areas. ${ }^{13}$

Sanctions regimes relevant to the EU are UNSC resolutions, EU Regulations and decisions which implement UNSC resolutions, autonomous EU restrictive measures, autonomous Member State regimes and third country regulations, such as US sanctions and export controls. UNSC Resolutions and the EU CSFP decisions are binding on Member States. However, they are not directly applicable to natural persons. UNSC Resolutions therefore have to be given effect to by UN Member States in applying the sanctions to the targets. However, once the EU issues UNSC implementing Regulations and EU Regulations giving effect to Council Decisions, the measures become binding on the EU nationals as EU regulations are directly applicable in EU Member States and the restrictive measures become applicable to the nationals of the relevant Member States.

Currently there are more than forty different EU sanctions regimes, most of which are mandated by the UNSC. These are related to arms, international repression, nuclear weapons non-proliferation, dual-use goods, telecommunications equipment and energy and gas products such the prevention of deep-sea drilling for Russia. Measures can also relate to precious metals, food, financial measures, and investments. Sanctions can target jurisdictions, sectors, sensitive products such as arms and dual-use goods and national persons where their assets are subject to freezes [13].

\subsection{Overall impact of sanctions}

As sanctions can have a very wide scope not being limited to particular entities only, they can prohibit or severely restrict the conduct of business and may limit trade and exports to certain countries. Sanctions can target persons associated with or related to terrorist activities or human rights violations. ${ }^{14}$ If the relevant parties do not comply

\footnotetext{
${ }^{12}$ Kadi I, Kadi and Al Barakaat International Foundation v Council and Commission (Joined Cases C402/05 P and C-415/05 P Kadi and Al Barakaat v. Council and Commission [2008] ECLI:EU:C:2008, (ECJ, 3.9.2008). Kadi v Commission and Council (Case T-85/09) [2010] ECLI:EU:T:2010:418, (GCEU, 30.9.2010). See Gordon [27].

${ }^{13}$ Ibid

${ }^{14}$ Council Decision (CFSP) 2020/1999 of 7 December 2020, Council Regulation (EU) 2020/1998 of 7.12.2020 concerning restrictive measures against serious human rights violations and abuses.
} 
with the relevant measures they can be subject to criminal penalties such as imprisonment, confiscation and/or administrative sanctions, such as fines. Because sanctions implementation is a sensitive issue closely related to state sovereignty, Member States implement sanctions in a non-uniform manner in accordance with their own strategic policy objectives, resulting in affected parties being subject to different consequences, depending on the state imposing the sanction, ranging from administrative penalties and reputational damage [26] to criminal liabilities. ${ }^{15}$

\subsection{Hierarchy of EU relevant CFSP sanctions regimes: UNSC, EU, and national restrictive measures}

EU Member States have to comply with sanctions issued by the UNSC, autonomous EU sanctions issued in addition to UNSC sanctions and third country sanctions with extra-territorial application, such as US sanctions. ${ }^{16}$ Hierarchically, UN sanctions occupy the top of the list of sanctions which the EU and UN Member States have to implement. $^{17}$

\subsubsection{UNSC sanctions}

UNSC sanctions producing binding effects on UN members are based on Chapter VII of the UN Charter and represent the highest level of sanctions that states have to comply with. Article 41 of the UN Charter defines UN sanctions. Under Article 25 of the UN Charter, all UN Member States agree to accept and carry out the UNSC's decisions' while under Article 2(2) of the UN Charter, UN members must fulfil the obligations assumed under the UN Charter. In addition, Article 48(2) of the UN Charter compels its members to carry out UNSC decisions through 'their action in the appropriate international agencies of which they are members'. Furthermore, Article 103 of the UN Charter commits UN member states to comply with the UN Charter in the event of conflict between obligations stemming from the UN Charter and other international agreements. Consequently, UN member states are obliged to comply with the obligations stemming from the UN Charter and the respective UNSC resolutions on sanctions implementation.

\footnotetext{
${ }^{15}$ The Netherlands imposes criminal liabilities for non-compliance with restrictive measures. See Lester [33].

${ }^{16}$ The UN sanctions list armed group's leaders, to prevent threat to peace, security, and stability in their own countries, for example the Houtis in regard to Yemen. The UN can also designate non-state entities which support their governments in violations of international humanitarian law or for human rights abuse in Myanmar, Zimbabwe and Belarus: 96/635/CFSP: Common Position of 28.10.1996 defined by the Council on the basis of Art. J.2 of the TEU, on Burma/Myanmar, OJ [1996] L 287/2, Council Common Position of 18 February 2002 concerning restrictive measures against Zimbabwe, OJ [2002] L 50/1; Council Regulation (EC) No 765/2006 of 18.5.2006 concerning restrictive measures against President Lukashenko and certain officials of Belarus, OJ [2006] L 34/1; UN imposes also freezes on funds targeting persons and entities involved in the nuclear proliferation programs of Iran and North Korea - See UNSC Resolution 1737 (2006) of 27.12.2006; UNSC Resolution 1718 (2006) 14.10.2006.

${ }^{17}$ Council Common Position of 27.122001 on the application of specific measures to combat terrorism, OJ [2001] L 344/93. As of September 2016, the EU is also authorised by the UN to adopt autonomous restrictive measures against members of ISIL/Da'esh and Al-Qaida.
} 


\subsubsection{Implementation of UNSC sanctions resolutions within the EU}

Under Article 3(5) and 21(1) and (2)(c) TEU, the EU commits its actions to be guided by '... respect for the principle of the UN Charter' and pursuant to Article 347 TFEU, the EU Member States have to consult in relation to obligations they have accepted 'for the purpose of maintaining peace and international security' which results in the adoption of regulations within the EU in relation to the UNSC resolutions under Article 215 TFEU.

UNSC sanctions are effected in the EU legal order through 'implementing regulations' initiated and decided upon by the Council. ${ }^{18}$ The regulations are based currently on Council decisions. However, the implementing regulations can also be based on prior Council regulations, which in their turn are based on Council common positions or declarations taken pursuant to UNSC Resolutions adopted prior to the entry into force of the current Treaties. ${ }^{19}$ This is noteworthy, because at that time, the CFSP, was separate from the competences of the Community, and CFSP measures were considered temporary and designed in response to political crises, and as such, were initially designed to preclude judicial review by the European Court of Justice. Generally, implementing regulations are limited to dealing with specific policies based on Article 291 TFEU and must contain no additional, complementary, or adjoining rules. However, the implementing regulations sometimes differ in content from the decisions upon which they are based, producing legal effects for those affected.

Such implementing regulations are non-legislative acts which can be published in the Official Journal. ${ }^{20}$ Although they are not adopted pursuant to a legislative procedure however, they are binding in their entirety and are directly applicable in all Member States. Consequently, the Member States do not need to implement additional measures or acts in order to give effect to the regulation. The particularities of the measure's implementation remain with the Member States.

In case the EU implementing regulation transposing the UNSC decision is not correctly implemented, the obligations concerning implementation of the UNSC sanctions under the UN Charter remain with the Member States. It should be noted that

\footnotetext{
1896/635/CFSP: Common Position of 28.10.1996 defined by the Council on the basis of Art. J.2 of the TEU, on Burma/Myanmar, OJ [1996] L 287/2, Council Common Position of 18 February 2002 concerning restrictive measures against Zimbabwe, OJ [2002] L 50/1; Council Regulation (EC) No 765/2006 of 18.5.2006 concerning restrictive measures against President Lukashenko and certain officials of Belarus, OJ [2006] L 34/1.

${ }^{19}$ S/RES/1333 (2000), Council Common Position of 27.12.2001 (OJ L344, 28/12/2001 P. 0093 - 0096); Council Regulation (EC) No 2580/2001 of 27 December 2001 on specific restrictive measures directed against certain persons and entities with a view to combating terrorism (OJ L344, 28/12/2001 P. 0070 0075), Council Implementing Regulation (EU) 2020/19 of 13.1.2020 implementing Article 2(3) of Regulation (EC) No 2580/2001 on specific restrictive measures directed against certain persons and entities with a view to combating terrorism, and repealing Implementing Regulation (EU) 2019/1337 (OJ L 8 I, 14.1.2020, p. 1)., Council Implementing Regulation (EU) 2020/1128 of July 2020 implementing Article 2(3) of Regulation (EC) No 2580/2001 on specific restrictive measures directed against certain persons and entities with a view to combating terrorism, and repealing Implementing Regulation (EU) 2020/19.

${ }^{20}$ Article 288 TFEU, Article 289 TFEU, Council Implementing Regulation (EU) 2020/1128 of July 2020 implementing Article 2(3) of Regulation (EC) No 2580/2001 on specific restrictive measures directed against certain persons and entities with a view to combating terrorism, and repealing Implementing Regulation (EU) 2020/19.
} 
the European Court of Justice ruled in Kadi and in subsequent case law that the Court has an obligation to review all acts of the EU for conformity with the Treaties, including measures giving effect to UNSC resolutions under Chapter VII of the UN Charter, which means that in case the UNSC resolutions contradict the Treaties, the resolutions should not be implemented. ${ }^{21}$ In case they are implemented regardless of that, they can be challenged in the Court of Justice of the European Union, national courts and the European Court of Human Rights (ECtHR). ${ }^{22}$

\subsubsection{EU competences and the legal bases for issuing restrictive CFSP measures}

The EU generally cannot adopt acts which are ultra vires, which means that every act which is adopted by the Union has to be rooted in a legal basis in the Treaties. This is why EU acts state the legal basis upon which they have been issued. This however is complicated to follow through in cases of implementing acts which have been reissued relisting the contestants. ${ }^{23}$ Such changes raise issues as to whether they constitute amendments or supplements to the legal act concerned, and raise even more issues, regarding whether the acts were of a legislative nature in the first place, depending on the adoption procedure followed. ${ }^{24}$

The EU Treaties confer, through legal bases, exclusive, shared or supporting competences on the Union, empowering the Union to legislate and adopt legally binding acts. The legal bases provide for the EU competences in the field, the procedure for adoption of acts, the type of act that can be adopted and may provide the degree of harmonisation allowed. Article 352 TFEU can be used as a legal basis, where the Union has not been empowered to legislate by a competence conferred by a legal basis in the treaties and the Union needs to attain objectives set out in the treaties. Pursuant to it, the Council must vote unanimously on a proposal from the Commission upon obtaining the consent of the European Parliament. However, because this article could be used to create a legal basis to confer upon the Union any competence which was not included in the Treaties, the German Federal Constitutional Court, ${ }^{25}$ has decided that Article 352 TFEU cannot be used to provide for Kompetenz-Kompetenz and that any use of Article 352 TFEU, requires approval by the German Parliament. ${ }^{26}$

Exclusive EU competences are listed in Articles 2(1) and 3(1) and (2) TFEU, shared competences are listed under Articles 2(2) and Article 4 TFEU and support-

${ }^{21}$ Joined Cases C-415/05 P and C-405/05 P, Kadi and Al Barakaat v Council [2008], ECLI:EU:C:2008:461; Case C-658/11 EP v Council (Mauritius), EU:C2014:2025, para 70, Case C-72/15 Rosneft, EU:C:2017:236, Case C-732/18 P, Rosneft v Council, ECLI:EU:C:2020:727.

${ }^{22}$ Joined Cases C-402/05 P and C-415-05 P, Kadi \& Al Barakaat v Council \& Commission, Judgment of September 3, 2008 (2008), ECLI:EU:C:2008:461, para. 97.

${ }^{23}$ Judgement C-130/10, Parliament v Council ECLI:EU:C:2012:472, paras, 96 - 112; See also Commission regulation (EC) No 1190/2008 of 28 November 2008 amending for the $\mathbf{1 0 1}^{\text {st }}$ time Council Regulation (EC) No 881/2002 of 27.05.2002, which was annulled by the General Court in Case T-85/09 Yassin Abdullah Kadi v European Commission, ECLI:EU:T:2010:418. See also Chachko [24].

${ }^{24}$ See Art. 288 TFEU, Art. 289 TFEU, Art. 290 TFEU, Art. 291 TFEU, Art. 352 TFEU; Also see some of the sanctions were issued under article 352, which entails the legislative procedure.

${ }^{25}$ Article 115g Status of the Federal Constitutional Court, "The status and constitutional functions of the Federal Constitutional Court and its judges may not be impaired...”, also see Art. 79 (3) Grundgesetz.

${ }^{26}$ Bundeesvervassungsgericht (BVerfGE) 2BvE 123, 267, 2BvE 2/08 (2009 Lissabon- Urteil). 
ing competences are listed under Articles 2(5) and 6 TFEU. The CFSP is not included in any of these and could be argued that the Union is not empowered to legislate in respect of the legislative procedures. However, Article 2(4) TFEU '... states that the Union shall have competence to define and implement a CFSP... 27 The European Treaties, under Article $47 \mathrm{TEU}$, provide for a single legal personality for the EU which should include the CFSP within it and Articles 21(2) and 24(1) TEU, ${ }^{28}$ the latter in particular, define what the scope of EU competence in relation to the CFSP is, specifying that the CFSP is 'subject to specific rules and procedures'. However, in order for competence to be conferred on the EU to create a CFSP, this has to be done, in accordance with the principle of conferral, pursuant to a legal basis in the Treaties. ${ }^{29}$ Article 25 TEU states how the Union conducts the CFSP through measures requiring the definition of guidelines by the European Council and the decisions it adopts define 'actions, positions and arrangements for the implementation of the decisions' concerning these actions and positions, which are further defined. ${ }^{30}$

The adoption of decisions and declarations and their implementation which define the actions that need to be undertaken by the Union in relation to the CFSP is carried out by the Council under the guidance of the European Council. Article 347 TFEU is also relevant in the area of CFSP, since it encourages Member States to consult in relation to measures they may need to adopt which are related to serious disturbances and to the maintenance of peace and international security.

These consultations, where they concern 'non-legislative activities, under the Rules of Procedure, are generally not open to the public although it is possible to get access to 'the Council's first deliberations on important new proposals' as they 'shall be open to the public'. ${ }^{31}$ It is interesting to note that the public can get access to the Council's voting results regarding non-legislative acts, as well as to the statements, the minutes and the items in the minutes relating to the adoption of these acts, and the results have to be made public. However, the essence of the procedure is cloaked, away from judicial review. ${ }^{32}$

${ }^{27}$ The paper does not cover the Common Security and Defence Policy which is also part of the Union's external action under Chapter 2, Section 2 of Title V TEU.

${ }^{28}$ Art. 24 TEU states that the '... Union's competence in matters of common foreign and security policy shall cover all areas of foreign policy and all questions relating to Union's security...'

${ }^{29}$ Consolidated Version of the Treaty on the European Union TEU [2010] OJ C83/1; Consolidated Version of the Treaty on the Functioning of the European Union (TFEU) [2010] OJ C83/47.

${ }^{30}$ Also see Art. 26(2), Art. 28, Art. 30 TEU (relevant to operational action and not to sanctions) and Art. 42(4), Art. 43 TEU Art. 42(2) TEU relevant for CFDP.

${ }^{31}$ Rules of Procedure of the European Council and the Council of Europe, Council Decision 2009/937/EU of 1 December 2009 adopting the Council's Rules of Procedure, O.J. L 325/35 (2009) Article 3(6), Article $8(1)$.

${ }^{32}$ Rules of Procedure of the European Council and the Council of Europe, Council Decision 2009/937/EU of 1 December 2009 adopting the Council's Rules of Procedure, O.J. L 325/35 (2009) Article 9(1); A Member State or the High Representative needs to make a proposal in order to start the process for imposing sanctions. Then, it is discussed within the geographical working groups and is supported by the political and security committee (PSC), COREPER and the working party of foreign relations counsellors (RELEX). The legal drafting section reviews the adoption of the proposal and then COREPER and the Council approve with unanimity the council proposed sanctions decision. https:// www.consilium.europa.eu/policies/sanctions. 


\subsubsection{The adoption procedure for restrictive EU measures (sanctions) under the CFSP}

The EU has extensive experience in 'designing, implementing, enforcing and monitoring' restrictive measures in the framework of the CFSP. It is important to streamline the implementation and strengthen the 'methods of sanctions implementation'. ${ }^{3}$ Under Article 21 of the Treaty on the European Union (TEU), the Council may issue sanctions consistent with the objectives of the CFSP against third countries, entities, and individuals. Article 24(1) TEU provides the legal basis for EU competence in CFSP matters. This empowers the EU to take actions in all areas of foreign policy with respect to Union security and requires it to consult with respect to the CFSP. ${ }^{34}$

The Court of Justice approved Article 215(2) TFEU as the 'correct legal basis' for adopting restrictive measures in its C-130/10 judgement. ${ }^{35}$ The procedure for the adoption of a restrictive CFSP measures by the EU entails two stages, pursuant to Chapter 2 Title V TEU, which Member States are required to comply with. These measures can be adopted with a decision by the Council pursuant to Article 29 TEU, defining the approach of the Union to a particular matter of a geographical or thematic nature. This constitutes the EU objective. ${ }^{36}$ Subsequently, pursuant to Article 215(1), the Council adopts decisions for imposing sanctions by qualified majority and in the case of the adoption of measures under Article 215(2) TFEU concerning natural or legal persons or non-state entities pursuant to Chapter 2 Title V TEU, they can follow the adoption procedure under Article 215(1) TFEU. ${ }^{37}$ The adoption of a Council decision is simultaneous with the adoption of a regulation, on the basis of Article 29 TEU, providing for restrictive measures regarding CFSP decisions. ${ }^{38}$

However, the Court has stated in its Bank Refah Kargaran judgment that CFSP decisions, and the regulations enacted pursuant to Article 215 TFEU to implement them may not be substantively identical. ${ }^{39}$ Additionally, because a restrictive measure can cause reputational harm, the European Court of Justice has stated in Bank

\footnotetext{
${ }^{33}$ Ibid., supra $\mathrm{n} 2$ and (doc. 15579/03), (doc. 15114/05), (doc. 10198).

${ }^{34}$ Art. 32, TEU.

35 Judgement of the Court (grand Chamber), C-130/10, European Parliament v Council of the European Union19 July 2012, ECLI:EU:C:2012:472, paras. 96 - 112.

${ }^{36}$ Council Decision (CFSP) 2020/1999 of 7.12.2020 concerning restrictive measures against serious human rights violations and abuses.

${ }^{37}$ The Court of Justice in C-130/10, European Parliament $v$ Council of the European Union, ECLI:EU:C:2012:472, legalised Art.215(2) as the legal basis for all restrictive measures including counter terrorism ones. Note that under Art. 75 TFEU provides for adoption of measures in the Area of Freedom Security and justice (AFSJ) in relation to preventing and combating terrorism and related activities, however it has not been used to enact counter-terrorist measures against non-state entities. Art. 75 TFEU concerns internal security. See Wessel [40].

${ }^{38}$ Kadi II, Joined Cases C-584/10 P, C-593/10 P \& C-595/10 P, Commission and Others v Kadi, [2013], ECLI:EU:C:2013:518.

${ }^{39}$ Case C-134/19 P Bank Refah Kargaran v Council, (Judgment of the Court 6 October 2020) para. 41., Note: Decisions are binding, however if they are addressed to somebody they are binding only upon them. If the Decisions are addressed only to the Member States, they will be binding only upon them and not on the persons listed in the decisions. Regulations on the other hand are binding and directly effective.
} 
Refah Kargaran that the Court has jurisdiction to adjudicate on damages sought by a natural or legal person who is harmed by the restrictive measures. ${ }^{40}$

\subsection{EU CFSP Sanctions Compliance and the EU Charter of Fundamental Rights (CFR)}

Following the adoption of the implementing regulations giving effect to UNSC Decisions or EU sanctions regulations, the former become directly effective from the date on which they are stated to come into effect. Consequently, the Member States' national competent authorities listed at the end of the sanctions resolutions are responsible for implementing the regulations. They are responsible for providing guidance to the entities which have to comply with the sanctions and are responsible for applying fines for sanctions breaches. The EU has created tools to assist the uniform implementation of the EU relevant sanctions with their EU Sanctions map, their financial sanctions database and their guidance notes and opinions. ${ }^{41}$ Additionally, the Commission provides information upon request for information and oversees the reporting obligations of the Member States regarding implementation issues, numbers of assets freezes and derogations from the sanctions. ${ }^{42}$ It monitors whether national penalties are appropriate and proportionate when comparing different EU states. The results of such monitoring can result in improvements in the efficacy of the measures concerned. The Commission manages an EU sanctions tool in the form of a free-ofcharge online platform ${ }^{43}$ which is independent from the help desk, and which enables self-assessment of compliance with EU sanctions. It is useful as it provides general guidance to EU SMEs on potential business activities which might be affected by the sanctions. ${ }^{44}$ The due diligence analysis tool is also important as acting on the early identification of red flags can prevent huge fines being imposed on entities in breach of sanctions. Notwithstanding the foregoing, entities that need to comply with sanctions in order to prevent fines, are often faced with conflicting sanctions and false positive hits and increased and often updated EU sanctions lists which can differ from and be complemented by separate Member States sanctions lists.

\subsection{EU Charter of Fundamental Rights Consideration}

The EU strengthens its position regarding ease of implementation and control over its sanctions regimes by utilising the most current technological means, assisting those implementing measures on the one hand, but inevitably also reminding about the hurdles that affected individuals face, due to the lack of an equivalently seamless fair and timely judicial process. ${ }^{45}$ This free-of-charge closer monitoring through technical

\footnotetext{
${ }^{40}$ Case C-134/19 P Bank Refah Kargaran v Council, ECLI:C:2020:793, para 49.

${ }^{41}$ https://sanctionsmap.eu/\#/main.

${ }^{42}$ See European Union Consolidated Financial Sanctions List, 23/12/2020.

${ }^{43} \mathrm{https}$ ://sanctions-tool.ec.europa.eu/.

${ }^{44}$ https://sanctions-helpdesk.eu/.

${ }^{45}$ Case C-134/19 P Bank Refah Kargaran v Council, ECLI:C:2020:793. See Gutman [29]. See Gutman [29].
} 
platforms, is reminiscent of constitutional oversight, and consequently requires improved transparency, especially with regard to avoiding subsequent ultra vires challenges, for example based on the Segi ${ }^{46}$ or Solange ${ }^{47}$ case law.

The Charter of Fundamental Rights has been formally binding since 2009 and enjoys the same legal status as the rest of the Treaties. Article 6(3) TEU states that 'fundamental rights shall constitute general principles of the Union's law'. Article 51 CFR provides that the Charter is addressed to the Member States only when they are implementing EU Law. Because the European Court of Justice has found that Treaty articles have direct effect where they are sufficiently clear and precise and unconditional, it can be argued that the Charter of Fundamental Rights provisions, which are sufficiently clear, precise and unconditional, would have direct effect and similarly to the Treaties, should be capable of being invoked by individuals. The Court's case law has confirmed that EU law entails the application of the fundamental rights guaranteed by Article 47 of the Charter of Fundamental Rights ${ }^{48}$ and that acts of institutions can be reviewed for conformity with fundamental rights. 49

\subsection{US sanctions and Examples of EU restrictive measures independent of the UNSC}

In addition to UN and EU sanctions, Member States have to be vigilant regarding third country sanctions such as those of the US. The US sanctions regime has a wide scope and is overseen by the Office of Foreign Assets Control (OFAC) which administers and enforces economic and trade sanctions based on US foreign policy and national security goals. US sanctions target among others foreign countries and regimes, the proliferation of weapons of mass-destruction and other threats to the national security and foreign policy of the US. The Office of Foreign Assets Control publishes lists with specially designated nationals (SDN), consolidated sanctions lists, and additional sanctions lists, which can be regularly updated and found on their website. However, OFAC provides for license authorisation which allows entities to engage in transactions such as the release of blocked funds, that otherwise would be prohibited.

The OFAC sanctions compose of export controls, primary and secondary sanctions which potentially apply also to non-US entities. Primary sanctions apply among others, where a US nexus can be established such as US nationality or a non-US person involved in business in the US, on US territory, transacting in US dollars, or exporting non-US products with controlled US content to embargoed states. Consequences for sanctions violations can be dire. The recent enforcement releases of the US Department of the treasury for example, informs about the subsidiary of Berkshire Hathaway Inc. which agreed to pay over four million US dollars to settle a

\footnotetext{
${ }^{46}$ Case C-355/04 P Segi and Others v Council [2007], ECLI:EU:C:2007:116.

${ }^{47}$ Solange II - BVfGE 73, 339, case number 2 BvR 197/83. See Kokott [31].

${ }^{48}$ Art. 47 CFR, Case C-617/10 Aklagaren v Hans Akerberg Fransson, ECLI:EU:C:2013:280, (ECJ, 26.2.2013).

${ }^{49}$ Case C-355/04 P Segi v Council [2007], EC:C:2007:116, para 51; Case C-732/18 P, Rosneft v Council, ECLI:EU:C:2020:727.
} 
potential civil liability for trade-related transaction and exports to Iran, because of mitigating circumstances which OFAC considered, allowing Berkshire not to paying the statutory penalty applicable in this matter, which amounted to $\$ 36,841,344 .{ }^{50}$

\subsection{Case law on Member States and EU restrictive measures independent of the UNSC}

A notable example of the EU restrictive measures adopted in addition to the UNSC measures is the EU Blocking Statute Regulation and the new Regulation aimed at preventing human rights violations. ${ }^{51}$ The EU Blocking Statute Regulation, for example, prohibits persons from complying with listed US sanctions which have extraterritorial effect against Cuba, Libya and Iran, unless prior authorisations have been obtained from the EU Commission. EU sanctions usually apply to everyone involved in the sanction violation chain as well as to the directors and any EU nationals, even if located outside of the EU, to entities incorporated in EU Member States, to their non-EU subsidiaries and to the EU dealings of entities incorporated outside of the EU. Non-compliance can affect the individuals involved, especially those in charge of the sanctions violation who can be criminally prosecuted, in addition to the company itself. As discussed, Member States can implement their own sanctions based on UNSC Resolutions, EU and US, and can also issue their own sanctions or grant authorisations under the regulations.

The Dutch Sanctions Act 1977 implements UN and EU sanctions in the Netherlands using the EU sanctions framework and states that the maximum penalty which the court can impose is up to $10 \%$ of the annual income of the parent company. ${ }^{52}$ The Dutch Cargo Company case illustrates the need for sanctions compliance. KLM was transporting goods from South Africa to Ecuador without a license, claiming that it did not know what type of goods they transported based on the airway bill. The Dutch Court held that the company had an independent obligation to investigate the transit of strategic goods, based on the level of its sophistication and professionalism and in view of the information contained on the airway bill, 'the company should have

\footnotetext{
${ }^{50}$ Pursuant to $\S 560.215$ (a) of the Iranian Transactions and Sanctions Regulations (ITSR)—which implements $\S 218$ (b) of the Iran Threat Reduction and Syria Human Rights Act of 2012 (Pub. L. 112-158) (TRA) and $\S 4$ of Executive Order 13628 - "an entity that is owned or controlled by a United States person and established or maintained outside the United States is prohibited from knowingly engaging in any transaction, directly or indirectly, with the Government of Iran or any person subject to the jurisdiction of the Government of Iran that would be prohibited pursuant to this part if engaged in by a United States person or in the United States." Section 560.701(a)(3) further states that "a civil penalty ... may be imposed on a United States person if an entity owned or controlled by the United States person and established or maintained outside the United States violates ... the prohibition set forth in $\S 560.215$."

${ }^{51}$ Council Regulation (EC) No. 2271/96 of November 22, 1996 protecting against the effects of extraterritorial application of legislation adopted by a third country, and actions based thereon or resulting therefrom and Commission implementing Regulation (EU) 2018/1101 of August 3, 2018 laying down the criteria for the application of the second paragraph of Article 5 of Council Regulation (EC) No. 2271/96; Council Decision (CFSP) 2020/1999 of 7 December 2020, Council Regulation (EU) 2020/1998 of 7 December 2020 concerning restrictive measures against serious human rights violations and abuses.
}

${ }^{52}$ Sanctions Act 1977. 
assumed that the goods had a military nature. ${ }^{53}$ The Dutch Blocking Statute case ${ }^{54}$ illustrates the consequences of misunderstanding the EU Blocking Regulation and the operating sanctions regimes. In this case, the Dutch Supreme Court confirmed in its judgment of 7 April 2020 that the EU Blocking Regulation did not prevent extradition of an Iranian national to the US for their alleged involvement in US export controls. However, the case was not concerned with US secondary sanctions which the EU Blocking regulation concerns.

\subsubsection{Conflicting and overlapping sanctions}

Important issues have arisen from the overlap of conflicting measures such as the issues which arose from the Blocking Statute aiming at preventing compliance of EU Member States with the US extra-territorially applicable sanctions on $\operatorname{Iran}^{55}$ or in relation to providing humanitarian aid in Syria. ${ }^{56}$ Issues arose from the simultaneous applicability of both sanctions and the challenges entities faced when they had to interpret the meaning of the sanctions and their applicability. It is established case law in the Netherlands that inability to understand the applicability or the novelty of sanctions is not sufficient grounds for non-compliance. ${ }^{57}$

In relation to the US-EU conflicting sanctions on Iran, the International Chamber of the Paris Court of Appeal ruled in the French case of Sofregaz $v$ NGSC, ${ }^{58}$ that breach of a contract on the basis of compliance with a US sanction was unjustified. ${ }^{59}$ In this case Sofregaz informed its Iranian counterparty that the financing institutions had refused to extend bank guarantees needed under the contract due to international sanctions against Iran. The Natural Gas Storage Company (NGSC) terminated the contract with Sofregas, resulting in Sofregaz starting a court case against their counterparty for termination of the contract, which was adjudged in favour of NGSC. In the appeal by Sofregaz the Paris Court of Appeal stated that, while the $E U$ and UN sanctions regimes formed part of international public policy, the US sanctions regimes did not. ${ }^{60}$ The unilateral sanctions established by the US against Iran could not be regarded as the expression of an international consensus as both the EU and

\footnotetext{
${ }^{53}$ Rechtbank Noord-Holland 24.4.2017, ECLI:NL:RBNHO:2017:3300.

${ }^{54}$ Blocking Statute Case ECLI:NL:HR:2020:623.

${ }^{55}$ Council Regulation (EC) No 2271/96 ('blocking statute').

${ }^{56}$ Council Regulation (EC) No 2271/96 ('blocking statute').

${ }^{57}$ Rechtbank Noord-Holland 24 April 2017, ECLI:NL:RBNHO:2017:3300.

${ }^{58}$ Paris Court of Appeal, Decision No. 19-07261 of 3.6.2020 Sofregaz v NGSC.

${ }^{59}$ Council Regulation (EC) No 2271/96 ('blocking statute') protecting against the effects of the extraterritorial application of legislation adopted by a third country, and actions based thereon or resulting therefrom (OJ L 309 29.11.1996), p. 10.

${ }^{60}$ UN Security Council Resolutions 1737 of December 23, 2006, 1747 of 24.3.2007, and 1803 of 3.3.2008, EU Council Regulations (EC) No. 423/2007 of 19.4.2007, (EU) No 961/2010 of October 25, 2010, and (EU) No. 267/2012 of 23.3.2012 concerning restrictive measures against Iran; Council Regulation (EC) No. 2271/96 of November 22, 1996 protecting against the effects of extraterritorial application of legislation adopted by a third country, and actions based thereon or resulting therefrom and Commission implementing Regulation (EU) 2018/1101 of 3.8.2018 laying down the criteria for the application of the second paragraph of Article 5 of Council Regulation (EC) No. 2271/96.
} 
France disputed the extraterritorial scope of these sanctions. The French court dismissed the US secondary sanctions, thus establishing that US secondary sanctions can be disregarded as internationally applicable law and could not be regarded as good reason for termination of a contract. This decision is insightful regarding the French courts' consideration of economic sanctions enacted by foreign countries as forming part of French international public policy and elucidated the impact of international sanctions on the validity of the enforcement of international arbitral awards. ${ }^{61}$

\subsubsection{Challenges to sending humanitarian funds into high risk jurisdictions}

Apart from the challenges commonly encountered in relation to the implementation of and compliance with restrictive measures, countries which are ridden with challenges may experience difficulties with reconstruction or with receiving humanitarian aid due to the multiple sanctions regimes running simultaneously or in conflict with one other. Since the beginning of the conflict in Syria in 2011, close to 11 million people have required humanitarian assistance and around five million have received humanitarian aid. ${ }^{62}$ This has been done through humanitarian agencies which usually work through partner organisations in Syria requiring a full range of financial services through formal banking-financial channels in order to implement their activities within Syria. ${ }^{63}$ However, because there is no single model of implementing sanctions and often parallel sanctions are imposed by different countries and organisations, there is a diminished willingness on the part of parties to provide humanitarian aid which requires ingenious navigation through numerous sanctions regimes, to structure humanitarian aid in a form allowing the processing of the necessary funds within Syria without violating sanctions imposed and incurring penalties. Therefore, obtaining the necessary EU and US licensing or receiving derogations, authorisations, or exemptions, may allow for the provision of humanitarian aid within these jurisdictions. Licensing relevant to non-governmental organisations (NGO) under the UN and Syrian regulations can be very broad allowing for the provision of a wide range of goods as long as they do not relate to reconstruction although it still requires detailed listing and description of goods. ${ }^{64}$ Consequently it is vital for those involved in humanitarian aid to follow closely the information regarding the parallel running sanctions regimes available at the relevant offices of the UN, the EU, the US, the UK and Switzerland.

\footnotetext{
${ }^{61}$ See also Rome Convention on the law applicable to contractual obligations, art. 7(1); Regulation (EC) No. 593/2008 of the European Parliament and of the Council of 17.6.2008 on the law applicable to contractual obligations (Rome I), (OJ L 177, 4.7.2008, p. 6) art. 9(3).

${ }^{62}$ Walker, Dr. Justine, Risk Management Principles Guide for Sending Humanitarian Funds into Syria and Similar High Risk Jurisdictions, May 2020, pg. 7.

${ }^{63}$ Walker, Dr. Justine, Risk Management Principles Guide for Sending Humanitarian Funds into Syria and Similar High Risk Jurisdictions, May 2020, pg. 33.

${ }^{64}$ Walker, Dr. Justine, Risk Management Principles Guide for Sending Humanitarian Funds into Syria and Similar High Risk Jurisdictions, May 2020, pg 21.
} 


\section{Restrictive Measures Judicial Review Challenges}

Although the general rules which govern CFSP decisions under Article 24(1) TEU and the first paragraph of 275 TFEU provide for a derogation from the general scope of the jurisdiction of the European Court of Justice under Article 19 TEU, as it was decided in $H v$ Council and in subsequent case law discussed below, this restriction has to be interpreted narrowly. ${ }^{65}$ Moreover the evolution of the recent caselaw provides for broadening of the grounds of review of the CFSP measures, the latest of which, based on the European Court of Justice decision of Bank Refah Kargaran where the European Court of Justice found that the General Court had erred in the law when concluding that they had no jurisdiction to hear actions for non-contractual damages. ${ }^{66}$

The Treaties provide for two ways to exercise control over the EU. Firstly, through ensuring the legislative acts are valid and that they have been issued following the correct procedure pursuant to the necessary purpose, as discussed in Part II, or failure to act pursuant to Article 265 TFEU. There are also actions for damages pursuant to Articles 268 TFEU for non-contractual damages under Article 263 TFEU. Since the CFSP is part of the EU and although the acts adopted pursuant to it, are amenable to judicial review, the case law in this area is still facing challenges which are gradually resolved through application of the fundamental rights principles gradually albeit not being able to uncloak the secrecy pervading the political grounds of the CFSP decisions.

Since the introduction of contemporary sanctions, the courts adjudicated a growing number of cases dealing with national security and foreign listed entities claiming that they suffered wrongfully because of illegal sanctions imposed on them. ${ }^{67}$ The early post 9/11 UNSC sanctions were preventative in response to international terrorism, punishing those who might commit wrongful acts. One could argue that current cases exhibit similarities in this respect, as some of the grounds for preventing the removal of persons from the designated persons lists in current restrictive measures regulations, base their reasoning on the 'prevention' of the transferring of the funds prior to the introduction of a following measure or a final decision.

In Kadi I, the General Court dismissed the case, because the sanctions could not be subject to judicial review. The Court considered that it could review the case if a jus cogens norm was violated, however it adjudged that there was no such violation. ${ }^{68}$ In Kadi II the final decision of the Grand Chamber of the European Court of Justice held that the procedures available for Kadi to appeal the listing by the UNSC in Europe did not meet the EU standards. ${ }^{69}$ This decision differed to the one taken by the US courts, where Mr Kadi was not allowed to rely on the decision taken by the ECJ in

\footnotetext{
${ }^{65}$ Case C-455/14 P, H v Council and Others, EU:C:2016:569, para 40. See Thanau [36].

${ }^{66}$ Case C-134/19 P Bank Refah Kargaran v Council (Judgment of the Court 6 October 2020) para 40.

${ }^{67}$ See Rosneft, Case C-72/1, EU:C:2017:236, paras. 65 - 66.

${ }^{68}$ See Kadi I, Joined Cases C-402/05 P \& C-415/05 P Kadi and Al Barakaat International Foundation v Council, [2008], ECLI:EU:C:2008:461, para 104. See Gordon [27].

${ }^{69}$ Kadi II, Joined Cases C-584/10 P, C-593/10 P \& C-595/10 P, Commission and Others v Kadi, [2013], ECLI:EU:C:2013:518.
} 
Kadi II as this was a different legal order applying different standards of evidence and judicial review. ${ }^{70}$

Because of the judgments in the Kadi cases and due to the realisation that the UN sanctions designation approach included individuals with similar names, the UN reformed, becoming more transparent and effective. It introduced the Ombudsperson whose purpose was to guarantee fair proceedings and to review petitions, allowing the petitioner to comment on the non-confidential parts of the reasons for the imposition of the sanction, bearing the responsibility to collect information and review individual's requests for delisting from the UN sanctions lists, in addition to the Sanctions Committee. ${ }^{71}$ The UN also introduced summaries in relation to every listing of persons in its targeted sanction in 2008. It seemed necessary that the manner in which the sanction system worked was further reformed since a number of listed persons have been delisted upon approaching the Ombudsperson with respect to sanctions targeting individuals. Following, the function of the ombudsperson is considered a 'quasi-judicial one counterbalancing the diplomatic nature of the proceedings within the Sanctions Committee,' since her decision is automatic and final unless unanimously opposed within 60 days. Nonetheless, the European Court of Human Rights (ECtHR) still considered that the requirements of fair trial were unsatisfactory since, the decisions on which the persons were listed were based to a great extent, on confidential information which was not available even to the affected persons. This decision represented a positive development compared to the one in the Bosphorus ${ }^{72}$ case where the ECtHR decided that it did not possess competence to review UNSC measures. ${ }^{73}$

Furthermore, there is an established practice where the people who do not have locus standi, since are not the persons listed on the sanction, cannot bring action in order to remove their names from the sanctions list, although they suffer from the fact that the financial institutions have acted upon the sanction by freezing the person's assets, because they cannot access their bank accounts, for example or get access to the capital markets.

In that respect the CFSP sanctions related case law, deals with natural and legal persons, among which, Venezuela is the only third country state. ${ }^{74}$ She joined the plethora of applicants seeking a judicial remedy through the European Court of Jus-

\footnotetext{
${ }^{70}$ Kadi v Geithner, No. 09-0108, 2012. See also for a discussion of confidential evidence and due process guarantees, Douglas Cantwell, "A Tale of Two Kadis: Kadi II, Kadi v. Geithner \& U.S. Counterterrorism Finance Efforts” (2015) 53 Colum J Transnat'1 L652.

${ }^{71} \mathrm{~S} / \mathrm{R} / 2368$ (2017). See also Cantwell Infra n69. See Riccardi [35] for a discussion on confidentiality in UNSC and CFSP evidenciary material.

${ }^{72}$ Case C-84/95 Bosphorus Hava Yollari Rurzm ve Ticaret AS v Minister for Transport, Energy and Communications and others, ECLI:EU:C:1996:312; Bosphorus/Ireland 45036/98. See Kokott [31].

${ }^{73}$ App. No. 27021/08 Al-Jedda/UK, judgment 2011, Nada/Switzerland, judgment 2012, paras 171, 176, also see Opinion 2/13 (Accession to ECHT) EU:C:2014:2454, para 252, where the Court held that as EU law now stands, certain acts adopted in the content of the CFSP fall outside the ambit of judicial review by the Court of Justice'. See Thanau [36] and Vara [38].

${ }^{74}$ Judgment of 13.12.2018, Ville de Paris, Ville de Bruxelles and Ayuntamiento de Madrid $\mathrm{v}$ Commission, T-339/16, T-352/16 and T-391/16, under appeal, EU:T:2018:927, paragraph 50.
} 
tice, claiming that she suffered wrongfully because of sanctions imposed on her. ${ }^{75}$ Venezuela, sought an action for annulment against three acts of the Council CFSP measures claiming that she was directly concerned by the provisions of the contested sanctions provisions, alleging she had locus standi to seek remedy on the grounds that the imposed measures produced legal effects for Venezuela and directly affected her legal situation. ${ }^{76}$ The Court dismissed the case in its entirety, stating that third countries do not have locus standi to seek judicial remedy as far as the sought measure was directed against the contested acts, and that it did not permit the conclusion that the contested measures were of 'direct legal concern' to Venezuela for the purposes of the fourth paragraph of Article 263 TFEU, because whether 'a measure directly affects the legal situation of an applicant depends on the content of that measure and not its objective', stating that Article 263 TFEU conditions are 'automatic' and that the way to 'determine whether a measure produces legal effects, it is necessary to review its subject matter, content and substance, the factual and legal context of its format'. ${ }^{77}$ Moreover, the name of Venezuela as a state was not explicitly and specifically referred to in the contested provisions, nor did she submit evidence proving that Venezuela was directly affected. Furthermore, the prohibitions were limited to the territory of the EU, to natural and legal persons concerning business having an EU nexus. Besides, the Court stated that regardless the fact that Venezuela would not be able to bring action before the Member States, because of the lack of implementing measure, resulting in deprivation of all judicial protection, the Court could not set aside the requirement for fulfilment of the cumulative conditions laid down in Article 263 TFEU. ${ }^{78}$ Effectively the ruling did not clarify the scope of Article 263 TFEU leaving a judicial review lacuna as regards to standing of third-country states.

Unlike the latter, in the Ben Ali case, the investigation for the designation of the applicant on the contested measure, was open since 2011, without giving rise to a judicial decision. The Court applied the principles derived from the Azarov judgment and noted that the applicant's rights to a decision within a reasonable time was a fundamental component of a right to an effective judicial procedure and that the Council was responsible to ensure that it had sufficient information concerning the state and

\footnotetext{
${ }^{75}$ Recent cases Case C-134/19 P Bank Refah Kargaran v Council, T-163/18, Amisi Kumba v Council, T-490/18, Neda Industrial v Council, Case T-151/18 Ben Ali v Council ECLI:EU:T:2020:514, Joint cases T-244/16 Yanukovych v Council, T-285/17, Yanukovych v Council, Joint cases T-245/16 and T286/18 Azarov v Council, ECLI:EU:T:2019:577; T-285/18, Pshonka v Council, ECLI:EU:T:2019:512, T-289/18 Pshonka v Council, ECLI:EU:T:2019:504, and T-305/18 Klyuyev v Council, ECLI:EU:T: 2019:506, Joint cases T-289/19 Arbuzov v Council, ECLI:EU:T:2020:445, T-291/19 Pshonka v Council, ECLI:EU:T:2020:448; T-292/19, Pshonka v Council, ECLI:EU:T:2020:449; T-295/19, Klymenko v Council, ECLI:EU:T:2020:287.

${ }^{76}$ Case T-65/18 Bolivarian Republic of Venezuela v Council of the European Union, ECLI:EU:T:2019: 649.

${ }^{77}$ Case T-65/18 Bolivarian Republic of Venezuela v Council of the European Union, ECLI:EU:T:2019: 649 , paras. $26,29,30$ and cited case law.

${ }^{78}$ Ibid., para 29, 'The two cumulative conditions are: the contested measure has to directly affect the legal situation of the applicant and it has to leave no discretion to its addressees who are responsible for its implementation'.
} 
progress of the procedure, in order to assess the risk of an infringement of that rights and to carry out such assessment with care an impartiality. ${ }^{79}$

Many sanctions therefore are struck down, based on procedural issues, such as lack of information to support the decision to list a certain entity or the failure to provide substantiating evidence for the reasons for listing the entity, while relisting the contestants under newly adopted measures. ${ }^{80}$ Since 2010 when the EU together with the international community, imposed sanctions on Iran to combat its weapons of mass destruction development, resulted in many listings of businesses which generated abundant litigation. ${ }^{81}$ This was followed by other countries sanctions regimes, which were all targeting the state governments for the repression of opposition. From the point of view of the legislators in the Council, it was using provisions which were outlined in the sanctions guidelines and all had the purpose to change the behaviour of the targeted regimes. ${ }^{82}$

It must be emphasized again, that in general the EU court has no jurisdiction to review the measures adopted in relation to the CSFP as they are a matter of foreign policy. ${ }^{83}$ However, limitations to the Article 19 TEU judicial review were interpreted narrowly in respect of CFSP measures. ${ }^{84}$ Additionally, it has been established by the courts that the only persons that have locus standi that can bring a case to the Court to contest an asset freeze or a travel ban, are the people who are listed in the measure. ${ }^{85}$ However, initially this was not so, even in the first Kadi case, the court stated that the Security Council resolutions fall outside the ambit of the judicial review of the court. ${ }^{86}$ However, in the subsequent Kadi cases the court confirmed that the 'fundamental rights form an integral part of the general principles of law which the Court ensures' allowing for review of the measures. ${ }^{87}$ Following, the Court stated that the 'respect for human rights is a condition for lawfulness of commission acts, and that measures incompatible with respect of human rights are not acceptable in the Community'. ${ }^{88}$ The Court further concluded that the measures which were imposed

${ }^{79}$ Case T-151/18, Ben Ali v Council, ECLI:EU:T:2020:514; C-58/19, Azarov v Council ECLI:EU:C:2019: 890.

${ }^{80}$ Kadi cases, Case T-65/18, Venezuela v Council, ECLI:EU:T:2019:649, Case C-134/19 P, Bank Refah Kargaran v Council; Chachko, Elena, Foreign Affairs in Court: Lessons from CJEU Targeted Sanctions Jurisprudence, p. 4. See Chachko [24].

${ }^{81}$ Christina Eckes, Common Foreign and Security Policy; The Consequences of the Court's External Jurisdiction, 22 Eur. L.J. 492, 510 (2016); Christina Eckes, EU Restrictive measures Against Natural and Legal Persons: From Counterterrorism to Third Country Sanctions, 51 CML. 869 (2014); Maya Lester \& Brian Kennelly, Judicial Review of Sanctions Decisions: The Wrong Point in the Wrong Court with the Wrong Defendant?, Judicial Review, 2013-06-24, Vol.18(2), p. 206-210 [33].

${ }^{82}$ Guidelines on the implementation and evaluation of restrictive measures (sanctions) - 4.5.2018.

${ }^{83}$ Art. 24(1) TEU, Art. 263(4) TFEU, Art. 275 TFEU.

${ }^{84}$ Case C-439/13 P Elitaliana, ECLI:EU:C:2015:753, para 41; C-455/14 P H V Council, ECLI:EU:C:2016:569, para 40., Case C-72/15, Rosneft, EU:C:2017:236, para. 66.

${ }^{85}$ Case T-515/15, Almaz-Antey v Council, EU:T:2018:545, para 65.

${ }^{86}$ Case T-315/01 Kadi v Council and Commission, [2005], ECLI:EU:T:2005:332.

${ }^{87}$ Kadi I, Joined Cases C-402/05 P \& C-415/05 P Kadi and Al Barakaat International Foundation v Council, [2008], ECLI:EU:C:2008:461, para 283.

${ }^{88}$ Ibid., para 284. 
by international obligations also had to be compatible with fundamental rights and had to ensure judicial review of the lawfulness of all community measures in light of the fundamental rights, resulting in states being able to decide on the manner in which they implement the UNSC Resolutions. ${ }^{89}$

With reference to targeted sanctions aimed at individuals, there exist also procedural and evidentiary issues. The current trend is that upon contesting the sanctions viability, the court provides as substantiation for the listings, various documentation collected initially by the participants of the relevant Committees engaged in support of the Council and the European Council. ${ }^{90}$ Such documents can vary in quality of substance, ranging from press reports to information provided by the competent authorities of the EU states or by the governments where investigating proceedings were initiated, which do not require quality check and can prove to be uncontestable. ${ }^{91}$ Such press reports are collected by the supporting working groups at the Council and the European Council, collecting evidence files in order to be used as evidentiary basis on which to include names of proposed designated persons and companies in the sanctions lists. The 'evidence' comprising the very press articles containing statements about individuals, can be hard to disprove.

Such evidence provided by the committees or through the National Competent Authorities, based on the ongoing judicial proceedings concerning the designated persons, cannot be considered by members of the committees supporting the Council as sufficient grounds for including persons on the individual targeted sanctions lists post Azarov. ${ }^{92}$ Since such documents are considered further in case there are court proceedings and relate to the standard of evidence that the Court accepts, however the procedure itself, is cloaked in secrecy as it represents the initial stage preceding the decisions voting by the Council and is currently not evaluated in compliance with human rights nor is subject to judicial review. Nevertheless, following from the Court ordered in Azarov, the above approach needs to change at least as to the Union judicature, which 'shall ensure that this decision, which is of individual significance for that person, rests on a sufficiently solid factual basis. 93

Other issues relate to overlapping grounds for inclusion or changes to the factual situation or relevance of the evidence supported by the Council. ${ }^{94}$ Another such example is the Rosneft case where the main objective of the measures, was to increase the costs of the actions taken by Russia against Ukraine's sovereignty, where the Court was not required to state actual or specific reasons for the imposition of the general restrictive measures, stating that the measures were of general applica-

\footnotetext{
${ }^{89}$ Ibid., paras. 285 and 326.

${ }^{90}$ The process of imposing sanctions starts with a proposal from a Member State or the High Representative and is discussed within the geographical working groups and is supported by the political and security committee (PSC), COREPER and the working party of foreign relations counsellors (RELEX). The legal drafting group reviews the adoption of the proposal and then COREPER and the Council approve upon unanimity the council proposed sanctions decision. https://www.consilium.europa.eu/policies/sanctions.

${ }^{91}$ Case T-510/18, Kaddour v Council ECLI:EU:T:2020:436.

${ }^{92}$ C-58/19, Azarov v Council ECLI:EU:C:2019:890; see also Case T-175/15, Mabrouk v Council, ECLI:EU:T:2017:694.

${ }^{93}$ C-58/19, Azarov v Council ECLI:EU:C:2019:890, paras. 26, 27.

${ }^{94}$ Case T-510/18, Kaddour v Council ECLI:EU:T:2020:436.
} 
tion, and concluding that the measures were not manifestly inappropriate with regard to the CFSP objective. ${ }^{95}$ In effect the Court did not allow for finding of direct and individual concern dismissing the illegality ground, because the appellant failed to supply evidentiary material supporting the claim, preventing the successful challenge of the measure, which was found 'not to be manifestly inappropriate', having regard to the objective which the EU was seeking to achieve, concluding that there was a reasonable relationship between the content of the contested act and the objectives pursued by those acts. 96

Finally, in Bank Refah Kargaran concerning EU autonomous sanctions regarding freezing of its funds, the European Court of Justice found that the General Court was not precluded from hearing actions for damages for harm allegedly caused by the adoption and maintenance of the restrictive measures adopted pursuant to Article 29 TEU. Subsequently the Court confirmed that the exception from jurisdiction under Article 275 should be interpreted restrictively. ${ }^{97}$ Thus, the finding that the court has jurisdiction to rule on actions for damages 'on illegality consisting in infringement of the right to effective judicial protection' regarding restrictive measures, issued based on CFSP decisions pursuant to Article 215 TFEU, provides for filling the lacuna of judicial protection regarding the protection of natural and legal persons. ${ }^{98}$ In this way the Court reaffirms the principle of Article 47 CFR, regarding effective judicial protection in line with what the Court stated in Rosneft, that the 'very existence of effective judicial review designed to ensure compliance with the provisions of EU law, is of the essence of the rule of law'. ${ }^{99}$

\section{Conclusion}

In conclusion, although the EU's CFSP's measures were considered temporary and designed in response of political crises and as such were initially designed to preclude judicial review by the European Court of Justice, even after the Lisbon Treaties adoption restructured the CFSP, and reframed the manner of designing the EU CFSP, introducing exceptions to the absence of jurisdiction for the European Court of Justice, the approach to the CFSP measures judicial review remained the same. While, the scope of the CFSP broadened and the Treaties introduced exceptions to the prohibition of judicial review of the CFSP, the CFSP remained under the cloak of the EU

\footnotetext{
${ }^{95}$ Case C-732/18 P Rosneft and others v Council, ECLI:EU:C:2020:727; see also Council Decision 2014/512/CFSP of 31 July 2014 concerning restrictive measures in view of Russia's actions, destabilising the situation in Ukraine; Council Regulation (EU) No 833/2014 of 31 July 2014, concerning restrictive measures in view of Russia's actions, destabilising the situation in Ukraine.

${ }^{96}$ Case C-732/18 P Rosneft and others v Council, ECLI:EU:C:2020:727, paras. 67, 91-93, 105-106.

${ }^{97}$ Case C-134/19 P Bank Refah Kargaran v Council, ECLI:C:2020:793 (Judgment of the Court 6 October 2020) para. 32 and case law cited and para. 49. "It follows from all the foregoing considerations that the General Court erred in law in holding, in paragraph 30 of the judgment under appeal, that an action for damages for harm allegedly suffered by a natural or legal person as a result of restrictive measures provided for by CFSP Decisions fell outside its jurisdiction."

${ }^{98}$ Case C-134/19 P Bank Refah Kargaran v Council, ECLI:C:2020:793, para 41.

${ }^{99}$ Ibid., para. 36, 49 and 77.
} 
Council decisions discretion, concealed from effective judicial review, consequently resulting in findings of lack of jurisdiction and admissibility, founded on procedural errors, reliance on inappropriate case law or lack of standing, complementing unclear standards of evidence and burden of proof. However, there has been gradual evolution of the scope of human rights and the recognition of the protection of fundamental rights as one of the general principles of the EU law, the exclusion of the CFSP judicial review currently has to be interpreted narrowly and the CFSP exceptions providing for judicial review are interpreted broadly. Furthermore, the recent caselaw acknowledges the role of domestic courts in relation to the EU CFSP providing for preliminary reference in relation to clarifications in relation to the CFSP and allowing the General Court to hear cases for damages suffered because of imposed restrictive measures. Finally, because CFSP based measures have broader reach, encompassing all involved in the implementation and compliance with the measures, including banks, companies and persons whose names match the names of those included on the sanctions lists, it is important to continue to follow the development of the caselaw in this area.

Publisher's Note Springer Nature remains neutral with regard to jurisdictional claims in published maps and institutional affiliations.

Open Access This article is licensed under a Creative Commons Attribution 4.0 International License, which permits use, sharing, adaptation, distribution and reproduction in any medium or format, as long as you give appropriate credit to the original author(s) and the source, provide a link to the Creative Commons licence, and indicate if changes were made. The images or other third party material in this article are included in the article's Creative Commons licence, unless indicated otherwise in a credit line to the material. If material is not included in the article's Creative Commons licence and your intended use is not permitted by statutory regulation or exceeds the permitted use, you will need to obtain permission directly from the copyright holder. To view a copy of this licence, visit http://creativecommons.org/licenses/by/ $4.0 \%$.

\section{References}

\section{Legal instruments}

1. Charter of the United Nations, International Law Documents, 14th edn. Blackstone's Statutes (2020)

2. Consolidated version of the Treaty on the European Union TEU. OJ C83/1 (2010)

3. Consolidated version of the Treaty on the Functioning of the European Union. (TFEU) OJ C83/47 (2010)

4. United Nations Security Council Resolution 1373 (2001) International Law Documents, 14th edn. Blackstone's Statutes, (2020)

5. Convention on the Law of the Treaties 1969, Law Documents, 14th edn. Blackstone's Statutes (2020)

6. Vienna Convention on the Law of the Treaties between States and International Organizations or between International Organizations (1986), International Law Documents, 14th edn. Blackstone's Statutes (2020)

7. Charter of Fundamental Rights of the European Union (Charter). OJ C364/1 (2000)

8. Council Regulation (EC) No 881/2002 of 27 May 2002 imposing certain specific restrictive measures directed against certain persons and entities associated with Usama bin Laden, the Al-Qaeda network and the Taliban, and repealing Council Regulation (EC) No 467/2001 prohibiting the export of certain goods and services to Afghanistan, strengthening the flight ban and extending the freeze of funds and other financial resources in respect of the Taliban of Afghanistan. OJ L139/9 (2002)

9. UN Security Council Resolution 1267/1999 
10. Council Regulation (EC) 337/2000 of 14 February 2000 concerning a flight ban and a freeze of funds and other financial resources in respect of the Taliban of Afganistan. OJ, no. L 43 (2000)

11. Council Regulation (EC) no. 561/2003 of 27 March 2003 amending, as regards exceptions to the freezing of funds and economic resources, Regulation (EC) 881/2002 imposing certain specific restrictive measures directed against certain persons and entities associated with Usama bin Laden, the Al-Qaida network and the Taliban. OJ, no. L 82, 1 (2003)

12. Council Regulation (EC) No 2271/96 ('blocking statute') protecting against the effects of the extraterritorial application of legislation adopted by a third country, and actions based thereon or resulting therefrom. OJ L 309, 10 (29.11.1996)

13. Guidelines on the implementation and evaluation of restrictive measures (sanctions) (4 May 2018)

14. Best practices for the effective implementation of restrictive (4 May 2018)

15. Basic principles on the use of restrictive measures (sanctions) (7 June 2004)

\section{Books}

16. Craig, P.P., De Burca, D.: EU Law Text, Cases and Materials, sixth edition. Oxford University Press, London (2016)

17. Eckout, P.: External Relations of the European Union. Legal and Constitutional Foundations. Oxford University Press, London (2004)

18. Hernandez, G.: International Law: Distance in International Law, second edition. Oxford University Press, London (2019)

19. Kanetake, M.: The UN Security Council and Domestic Actors, first edition. Routledge, London (2018)

20. Mendez, M.: The Legal Effects of EU Agreements, Maximalist Treaty Enforcement and Judicial Avoidance Techniques, first edition. Oxford University Press, London (2013)

21. Wessel, R.A., Larik, J. (eds.): EU External Relations Law: Text, Cases and Materials 2nd edn. Hart Publishing, Oxford (2020)

22. Tridimas, T., Schutze, R. (eds.): The Oxford Principles of European Union Law. The European Union Legal Order, vol. 1. Oxford University Press, London (2018). Wessel, R.A., Eckes, C.: The European Union from an International Perspective, Sovereignty, Statehood, and Special Treatment. Amsterdam Centre for European Law and Governance

\section{Articles}

23. Buszewski, S., Gott, H.: Avoiding Kadi - Pre-Emptive Compliance with Human Rights when Imposing Targeted Sanction. Ger. Yearb. Int. Law 57, 507 (2014)

24. Chachko, E.: Foreign affairs in court: lessons from CJEU targeted sanctions jurisprudence, p. 4

25. Nanopolous, E.: Judicial review of measures implementing security council resolutions: the relevance of the EU principle of loyal cooperation. Camb. Yearb. Eur. Legal Stud. 15, 669 (2012)

26. De Burca, G.: The European Court of Justice and the International Legal Order after Kadi. https://jeanmonnetprogram.org/paper/the-european-court-of-justice-and-the-internationallegal-order-after-kadi/. Accessed on 19th December 2020

27. Gordon, J.: The United Nations Security Council and the emerging crisis of legitimacy. Yale J. Int. Aff. 40, 9 (2004)

28. Gordon, J.: The United Nations Security Council and the emerging crisis of legitimacy. Yale J. Int. Aff. 40, 9 (2014)

29. Gutman, K.: The essence of the fundamental right to and effective remedy and to a fair trial in the case-law of the court of justice of the European Union: the best is yet to come? Ger. Law J. 20, 9 (2019). https://doi.org/10.1017/glj.2019.67, Cambridge University Press

30. Hilpod, P.: EU law and UN law in conflict: the Kadi case. Max Planck Yearb. U. N. Law 13, 141 (2009)

31. Kokott, K.: The Kadi Case - constitutional core values and international law - finding the balance? Eur. J. Int. Law 23(4) (2012) (Oxford University Press)

32. Larik, J.: The Kadi Saga as a tale of 'Strict Observance' of International Law: obligations under the UN Charter, targeted sanctions and judicial review in the European Union. Neth. Int. Law Rev. 61, 23-42 (2014) 
33. Lester, M., Kennely, B.: Judicial review of sanctions decision: the wrong point in the wrong court with the wrong defendant. Judic. Rev. 18, 206 (2013)

34. Nanopolous, E.: The implementation of security council resolutions in the European Union revisited. Hung. Yearb. Int. Law Eur. Law 2013, 19 (2013)

35. Riccardi, A.: Revisiting the role of the EU judiciary as the stronghold for the protection of Human Rights while countering terrorism. Glob. Jurist 18(2), 188 (2018) (Walter de Guyter Gmbh)

36. Thanau, S.: Individual restrictive measures and actions for damages before the General Court of the European Union. ERA Forum (2020)

37. Tzankopolous, A.: Collective Security and Human Rights. In: de Wet, E., Vidmar, J. (eds.) Hierarchy in International Law: The Place of Human Rights, vol. 42, pp. 63-64. Oxford University Press, Oxford (2012)

38. Vara, J.S.: The consequences of Kadi: where the divergence of opinion between EU and international lawyers lies? Eur. Law J. 17(2), 252-274 (2011) (Oxford, UK, Wiley)

39. Vatsov, M.: Security Council Referrals to the ICC and EU Fundamental Rights: a Test for ECJ's Stance in Kadi I. Stance in Kadi I. Hague Yearbook of International Law, vol. 25, p. 79 (2012)

40. Wessel, R.A., Larik, J.: Common Foreign, Security and Defence Policy, EU External Relations Law: Text, Cases and Materials, 2nd edn. Hart Publishing, Oxford (2020), Chapter 9

41. Wessel, A.R., Bottner, R.: The procedures leading to the adoption of decisions in the CFSP area Art. 31 TEU. In: Blanke, H.-J., Mangiameli, S. (eds.): The Treaty on European Union (TEU): A Commentary. Springer, Berlin (2013) (forthcoming)

42. Zanfir, G.: The national judicial treatment of the ECHR and EU laws: a comparative constitutional perspective. In: The Interaction Between Europe's Legal System, Judicial Dialogue and the Creation 2013 RRDE, p. 181 (2013) 